Food Hygiene Research Dept.

Animal Health Res. Inst .

\title{
LEVELS OF SOME HEAVY AND TRACE ELEMENTS IN KAREISH CHEESE \\ (With 2 Tables)
}

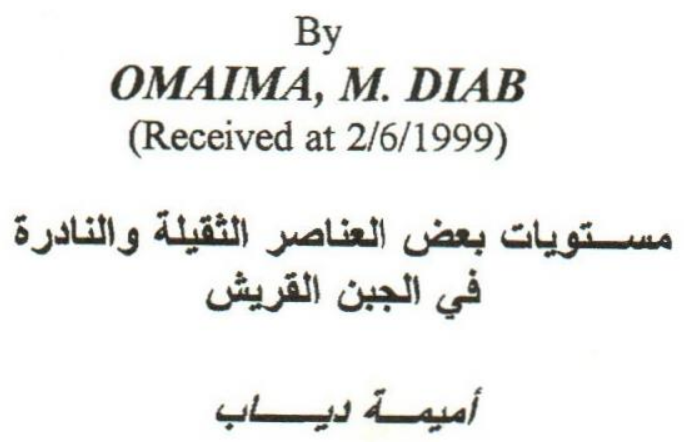

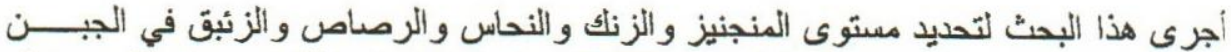

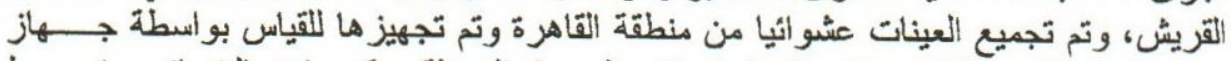

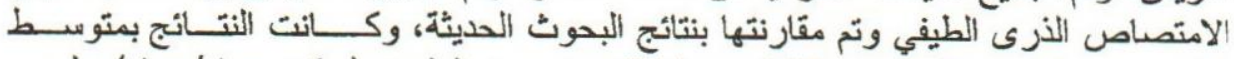

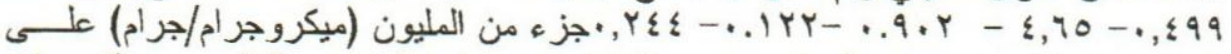

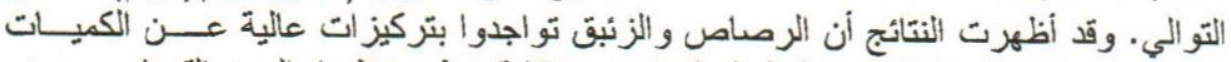

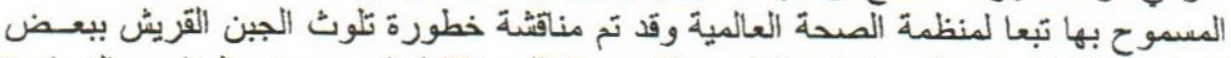

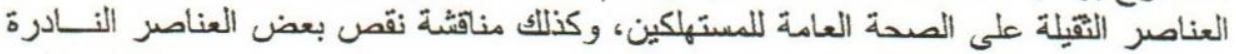
على صحة الأنسان.

\section{SUMMARY}

The present study was carried out on twenty Kareish Cheese samples collected randomly from Cairo City. The levels of Manganese, Zinc, Copper, Lead and Mercury in Kareish Cheese were determined by Atomic absorption spectorophotometry. The averages of metal levels were $0.499,4.65,0.902,0.122$ and $0.244 \mathrm{ug} / \mathrm{g}$ respectively, our data shows that lead and Mercury in Kareish Cheese were higher than the acceptable dietary intake of heavy metals by FAO/WHO.

Key Words: Food Hygiene, trace and toxic elements in Kareish cheese. 


\section{INTRODUCTION}

The presence of xenobiotic substances in foodstuffs is today more than ever a cause of concern onto which the interest of consumers, the mass - media and the scientific community is continously focused. (Coni et al., 1994).

In this connection it is worth recalling that the content in food of toxic metals such as $\mathrm{Cd}, \mathrm{Hg}$ and $\mathrm{Pb}$ in some cases can reach threshold levels (Nielsen, 1974, Langard and Norseth, 1977; Mills et al., 1985). As well as of any other which may be recognized to pose a risk in the near future (eg. $\mathrm{Al}, \mathrm{Be}, \mathrm{Pt}$ and $\mathrm{Tl}$ ) reach toxic level. All foodstuffs present the problems of hygienic safety, especially products of animal origin (Stevens, 1991)

The rationalization of production processes and identification of quality markers for milk and milk products is of great importance for the protection and evaluation of typical dairy products. Consequently, as a safeguard, the first objective is to undertake a careful and thorough assessment of all mechanisms by which foodstuff quality manufacturing processes and environmental conditions, including health parameters, can influence milk and cheese properties.

The concentration ranges of certain health - related elements in milk and cheese are closely dependent upon animal species and feeding, time of season of sample collection, environmental conditions and manufacturing processes.

The composition of the mineral fraction of milk products has been frequently considered, but only a few published papers deal with minor and trace elements, despite their importance in nutrition or in food contamination. (Favretto et al., 1987; Gabrielli Favretto et al., 1989; Gabrielli Favretto 1990; Vojnovic et. al., 1991). Investigations on the presence and role of trace elements in dairy products is being promoted at international level in order to elucidate aspects that are still poorly understood (IDF, 1978; WHO, 1989)As Kareish cheese is one of the most important foods of animal origin. As it has all the nutrients necessary for a healthy diet. It is the main food for some consumer groups, such as infants and the elderly.

Therefore the aim of this work is to estimate the amount of trace and toxic element in Kareish cheese and to compare it with the international levels. 


\section{MATERIAL and METHODS}

Twenty random samples of Kareish cheese were collected from different localities in Cairo City. The collected samples were transferred to the laboratory for heavy metal analysis.

The extraction of different Kareish cheese was conducted according to Italian Official Analytical Methods (Ministerial Decree, 1986). Dry aching procedure at a relatively low temperature, but with a high efficiency of combustion and low risk of contamination was adopted.

The digested and filtrated samples were prepared for measurement of the levels of lead, copper, mercury, zinc and manganese in each sample by using the Atomic Absorption Spectrophotometer AAS 5FL interfaced with a deuterium lamp for background correction. (Ministerial Decree, 1986)

Analytical quality control. as background corrections were performed for all elements. Blanks were also run with each batch of ten samples. Standard mineral solutions were used to calibrate the AAS with each batch of samples. Samples were run in duplicate and the average was calculated.

\section{RESULTS}

The obtained results were tabluated in Tables 1 and 2 .

\section{DISCUSSION}

The levels of Manganese, Zinc, Copper, Lead and Mercury in Kareish cheese were recorded as wet material in Table 1, they were $0.499,4.65,0.902,0.122$ and $0.244 \mathrm{ug} / \mathrm{g}$ respectively.

Regarding the Manganese level, the data for Kareish cheese is in agreement with values reported by, Jorhem et al, 1989 in meat and Khalil and Gharaibeh 1993 in canned cheese. Manganese is regarded as an essential element in man's diet and the recommended daily intake for adults is in the range $2.5-5 \mathrm{mg}$ according to the Food and Nutrition Board, 1980. In the experimental work, it has been shown to be needed for the activation of phosphates in the formation of bone, activation of other enzymes, necessary for normal reproduction and for the utilization of thiamin. 
As for the Zinc level. The recorded ranged from 1.7 to 5.5 with an average of $4.65 \mathrm{ug} / \mathrm{g}$ as in table 1. This data is in agreement with Jorhem et al, and 1989. and with Khalil and Gharaibeh, 1993 and is comparable to Coni, et $\underline{\text { al, }}, 1994$ and Coni et al, 1996. In 1980 the Food and Nutrition Board considered zinc an essential metal and a daily intake of $15 \mathrm{mg}$ has been recommended for adults. Zinc is one of the trace elements essential to growth and well-being. No evidence has been reported of any zinc deficiency in human nutrition except in Egypt and Iran. (Eminians, 1967)

Copper is an essential element for all plants and animals. It is widely distributed and always presents in food. The level of cu ranged from 0.13 to 1.99 with an average of $0.902 \mathrm{ug} / \mathrm{g}$ as shown in table 1 . These data are in agreement with that of Khalil and Gharaibeh, 1993 (in feta cheese) and with Fathi et al, and 1995 (in milk powder). Copper is closely associated with iron in nutrition. A deficiency of copper results in an anemia, because without copper present, the body is unable to make use of its iron reserve to form hemoglobin. So that copper kettle used in the manufacture of swiss Cheese.

Considering $\mathrm{Mn}, \mathrm{Zn}, \mathrm{Cu}$ they are essential element for man's health. The importance of trace elements has been recognized in the maintenance of optimum nutritional health, as well as, in the beneficial effects of more complete in formation for use in nutritional labeling Rockland et al, 1979.

On the other hand heavy metals are considered the most important group of pollutants so, it is necessary to monitor the level of heavy metals contaminants, which may be present, to prove that the product is nutritious and healthy foods.

Hygienic standards of the contents of foreign substances in food, state that 0.1 PPM is the maximum lead content in milk (Bartik and Piskac, 1981). Table 1 showed those $\mathrm{Pb}$ levels in Kareish cheese ranges from 0.049 to 0.275 with an average of $0.122 \mathrm{Ug} / \mathrm{g}$. Hence, examined cheese samples were above this maximum recommended limit. Lead is considered one of the most important pollutant in our environment and widely distributed in classes of natural foods(Shehata and Nagah, 1992). But in the present study the level of $\mathrm{Pb}$ is less than that recorded by Khalil and Gharaibeh, 1993 in Feta Cheese $(0.3 \mathrm{mg} / 100 \mathrm{~g})$ and Madeha, et al., 1994 in milk products (1.501 ppm)

Regarding Mercury, its an average of mercury in Kareish cheese is $0.244 \mathrm{ug} / \mathrm{g}(0.075 \mathrm{ug} / \mathrm{g} \mathrm{min}$, and $0.634 \mathrm{Ug} / \mathrm{g}$ max $)$. This result is similar 
to $\mathrm{Hg}$ in milk that recorded by Gomez and Markakis, (1970) Matvijcuk et al, (1987) Riolfatti and Veronese 1990, and Madeha et al, (1994).

Mercury is not essential for man. Due to its affinity to sulfhydryl group in protein, its compounds are potent enzyme poisons (Rossi and Santaroni, 1976). It causes neurological effects and embryotoxicity (Carl, 1991). Moreover, it causes several kidney damage in both man and animal (Manahan, 1989).

From the obtained result, it is noticed that the concentration of lead and mercury are comparatively higher in Kareish cheese than the acceptable dietary intake of heavy metals by FAO/WHO Expert Committee on Food Additives (1972).

In conclusion, the high levels of lead and mercury recorded in examined Kareish cheese constitutes a possible health hazardous effect for human consumers. A regular and representative monitoring of heavy metals contamination of Kareish cheese at an appropriate frequency is recommended.

\section{REFERENCES}

Bartick M. and Piskac A, (1981): Veterinary toxicology. $1^{\text {st }}$ ed. Elsevier Scientific publishing company Amsterdam, Oxford, New Your, P.108-118.

Carl M. (1991): Heavy metals and other trace elements. Monograph on residues and contaminants in milk and milk products. Chapter 6 International Dairy Federation, Belgium

Coni, E., Caroli, S., Ianni, D. and Bocca, A. (1994): A methodological approach to the assessment of trace elements in milk and dairy products. Food Chem. 50, $203-210$

Coni,E., Bocca, A., Coppolelli, P. Caroli, S., Cavallucci, C., and Trabalza Marinucci, M., (1996): Minor and trace element content in sheep and goat milk and dairy products. Food Chem. 57, $253-$ 260

Eminian, J (1967) Clin, Ped 6: 603. Cited after Lampert, L.M. (1975): Modern Dairy Product $3^{\text {rd }}$ Ed Chemical Publishing Company, Inc. New York.

FAO/WHO, Joint Expert Committee on Food Additives, WHO Technical Report Series No. 505 (1972): No. 555 (1974c); No. 751 (1987) and No. 776 (1989): Evaluation of certain Food additives and contaminants, Geneva. 
Fathi, M., Nagah M. SAAD and Nagwa M. El. Sawi, (1995): Trace metal levels in some selected food items. J. Egypt Vet. Med. Ass. 57, No. 1: $165-178$

Favretto, L., Pertoldi Marletta, G., Gabrielli Favretto, L. and Vojnovic, $D$. (1987): Principal component analysis for the estimation of interdependencies among trace metals in cow milk. Anal. Chim. Acta, 201, $253-262$

Food and Nutrition Board (1980): Committee on Dietary Allowances recommended dietary allowances. National Academy of Sciences, Washington

Gabrielli Favretto, L., Pertoldi Marletta, G., Bogoni, P. and Favretto, L. (1989): Chemometric studies of some trace elements in cow's milk. Z. Lebensm. Unters. Forsch., 189, 123 - 127.

Gabrielli Favretto, L. (1990): Investigation of trace element content of cheese. Food Addit. Contam., 7, 425-432

Gomez M.I. and Markakis P. (1970): Mercury content of some foods. J. Food Sci. 39: $673-675$

IDF (1978): Metal contaminants in milk and milk products (Document 105). International Dairy Federation, Brussels, Belgium.

Jorhem L, Sundstrom B, Astrand C, Haegglund G (1989): The levels of Zine, Copper, Manganese, Selenium, Chromium, Nickel, Cobalt and Aluminium in meat, liver and kidney of Swedish pigs and cattle. Int. J.Food Res. Technol. 188. 39-44

Lampert, L.M. (1975): Modern Dairy Product. $3^{\text {rd }}$ Ed. Chemical Publishing Company, Inc. New York.

Khalil I. Ereifej, and Gharaibeh S.H. (1993): The levels of Cadmium, Nickel, Manganese, Lead, Zinc, Iron, Tin, Copper and Arsenic in the brined Canned Jordanian Cheese. Zlebensm Unters Forsch. 197: $123-126$

Langard, S. and Norseth, T. (1977): Toxicology of Metals National Technical Information Service, Springfield.

Madeha, A.A. Ayoub; Abd-El-Kader, M.R. and Tork, I.Y. (1994): Lead, Cadmium and Mercury in milk products. Assiut Vet. Med. J. Vol. 30 , No. $60,139-146$

Manahan, S.E. (1989): Toxicological chemistry. A guide to toxic substances in chemistry. Brooks/Cole publishing Co. C.A.

Matvijcuk V.M., Zulentko V.N., Belousov A.L., Cvirko I.P. and Pazout V. (1987): Mercury in milk and milk products Veterinarstvi, 37 (11): $491-493$. 
Mills, C.F., Brenner, G., Chester, J.K. (1985): Trace elements in man and animals. Proceedings of the Fifth International Symposium on Trace Elements in Man and Animals. Commonwealth Agricultural Bureaux.

Ministerial Decree (1986): Gazzetta Unfficiale Repubblica Italiana, Gen. Ser. 229, 20 October 1986.

National Research council (1989): In Recommended Dietary Allowances, $10^{\text {th }}$ ed, pp. $224-230$. Washington DC: National Academy Press

Nielsen, F.H. (1974): Ultratrace elements in nutrition Ann. Rev. Nutr. 4, 21.

Riolfatti M. and Veronese M. (1990): Heavy metals in milk Formulas. Igiene Moderna, 93 (6): 1090 - 1100. Food Sci. Techn. Abstract, 23 (4), 1991

Rockland, L.B.;Wolf, W.R.; Hahn, D.M. and JYoung, R. (1979): Estimation of Zinc and Copper in raw and cooked legumes: An interlaboratory study of atomic absorption and $\mathrm{x}$-ray fluoresce spectroscopy. J. Food. Sci., 4: $1711-1716$

Rossi L.C. and Santaroni M.S. (1976): Mercury and Selenium distribution in a defined area and its population. Archives of Environmental Health, P. $160-165$

Shehata A. and Nagah M.S. (1992): Lead content in milk of lactating animals at Assiut Governorate. Assuit Vet. Med. J. 26 (52): 135 141

Stevens, J.B. (1991): Disposition of toxic metals in the agricultural food chain. 1. Steady-state bovine milk biotransfer factors. Environ. Sci. Technol., 25, $1289-1294$

Vojnovic, D., Procida, $G$ and Gabrielli Favretto, L. (1991): Chemometric differentiation of raw and commercial milk by trace elements using principal component analysis. Food Addit. Contam., 8, $343-349$

World Health Organization (1989): Minor and Trace Elements in Breast Milk. Report of a joint WHO/International Atomic Energy Collaborative Study. 
Table 1: Statistical analytical results of some trace and heavy elements (Ug/g wet weight) in Kareish cheese.

\begin{tabular}{|l|c|c|c|c|}
\hline Element & $\begin{array}{c}\text { No of examined } \\
\text { samples }\end{array}$ & Minimum & Maximum & $\begin{array}{c}\text { Mean } \\
\text { I S.E. }\end{array}$ \\
\hline Manganese & 20 & 0.297 & 0.717 & $0.499 \pm 0.039$ \\
Zinc & 20 & 1.70 & 5.50 & $4.65 \pm 0.23$ \\
Copper & 20 & 0.13 & 1.99 & $0.902 \pm 0.028$ \\
Lead & 20 & 0.049 & 0.275 & $0.122 \pm 0.001$ \\
Mercury & 20 & 0.075 & 0.634 & $0.244 \pm 0.013$ \\
\hline
\end{tabular}

Table 2: Manganese, Zinc, Copper, Lead and Mercury levels in Kareish cheese as compared with the maximum tolerance level of human consumption in $\mathrm{mg} / 2$ og. wet material.

\begin{tabular}{|l|c|c|l|}
\hline \multicolumn{1}{|c|}{ Element } & $\begin{array}{c}\text { Mean } \\
\text { mg/20g }\end{array}$ & $\begin{array}{c}\text { Daily } \\
\text { intake }\end{array}$ & \multicolumn{1}{c|}{ References } \\
\hline Manganese & 0.01 & $2.5-5 \mathrm{mg}$ & Food and Nutrition Board(1980) \\
\hline Zinc & 0.093 & $15 \mathrm{mg}$ & Food and Nutrition Board(1980) \\
\hline Copper & 0.018 & $1.5-3 \mathrm{mg}$ & National Research Council (1989) \\
\hline Lead & 0.00144 & $0.05 \mathrm{mg} / \mathrm{kg}$ body weight & FAO/WHO \\
\hline Mercury & 0.0049 & $0.005 \mathrm{mg} / \mathrm{kg}$ body weight & FAO/WHO \\
\hline
\end{tabular}

